\title{
MOTERŲ PO KRŪTIES VĖŽIO OPERACIJOS REABILITACIJA, TAIKANT ŠIAURIETIŠKĄ ĖJIMĄ
}

\author{
Eglè Kalvaitiené2 $\dot{2}^{2}$ Alma Gaupšiene் $\dot{1}^{1}$, Laimutė Samsoniené ${ }^{1}$ \\ ${ }^{I}$ Vilniaus universiteto Medicinos fakulteto Sveikatos mokslu institutas, \\ ${ }^{2}$ Nacionalinio vėžio instituto Fizinès medicinos ir reabilitacijos skyrius
}

Raktažodžiai: fizinis aktyvumas, šiaurietiškas ejjimas, reabilitacija, psichomotoriniai parametrai, krūties vėžys.

\begin{abstract}
Santrauka
Šiaurietiškas èjimas - fizinès veiklos forma, gerinanti žmogaus judrumą, mažinanti jautrumą skausmui, gerinanti limfos nutekejjimą, tad gali būti rekomenduotina vèžiu sergantiems pacientams.

Tyrimo tikslas - fizinès reabilitacijos laikotarpiu nustatyti šiaurietiško ejjimo poveikị moterų psichomotoriniams parametrams, taikant spindulinị gydymą po krūties véžio operacijos.

Metodika. Atliktas eksperimentinis tyrimas, kuriame dalyvavo 40 moterų (amžius $=55 \pm 19$ ) po krūties véžio operacijos. Buvo vertinami psichomotoriniai parametrai: plaštakos raumenu jèga - dinamometru, limfedemos laipsnis - centimetrine juostele, jaučiamas skausmas- vaizdinès analogijos skale (VAS), tolerancija fiziniam krūviui - 6 min. èjimo testu. Matavimai buvo vykdomi du kartus, prieš fizinès veiklos taikymą ir po jos.

Rezultatai. Šiaurietiško ejjimo užsièmimai vyko 12 kartų, kiekvieno trukmè - 60 minučių. Po fizinès veiklos taikymo nustateme tiriamujų psichomotorinių parametrų pokyčius: žasto judesių amplitudė vidutiniškai pagerejo: lenkimas 17 laipsnių ( 51,5 proc.), atitraukimas 18 laipsnių (56,75 proc.), tiesimas 5 laipsniais (11,5 proc.); 6 min. ejjimo atstumas vidutiniškai padidejo 36 metrais ( 84,3 proc.). Skausmas sumažejo vidutiniškai 0,5 balo (32,3 proc.).

Išvados. Reabilitacijos metu adaptuota šiaurietiško ejjimo fizinès veiklos forma pagerino pacienčių psichomotorinius parametrus: pagerejo žasto funkcija, tolerancija fiziniam krūviui, sumažèjo skausmas spindulinio gydymo metu.
\end{abstract}

\section{İvadas}

Sergamumas vėžiu nuolat didejja. PSO duomenimis, kasmet nuo véžio miršta daugiau kaip $6 \mathrm{mln}$. žmonių. Prognozuojama, kad $2020 \mathrm{~m}$. nuo véžio gali mirti apie $10 \mathrm{mln}$. žmonių, o naujų vėžio atvejų skaičius viršyti 15 milijonų [1]. Europoje ir Lietuvoje krūties véžys yra pati dažniausia ir bene labiausiai paplitusi moterų onkologinè liga. Lietuvos moterų sergamumas krūties vėžiu yra maždaug dvigubai mažesnis, nei Prancūzijoje, Olandijoje ar Suomijoje, bet mirtingumas nuo krūties véžio Lietuvoje ir šiose šalyse beveik vienodas [2]. Remiantis Nacionalinio véžio instituto Véžio kontrolès ir profilaktikos centro duomenimis, $2012 \mathrm{~m}$. Lietuvoje buvo nustatyti 1526 moterų krūties vėžio atvejai. Mirtingumas nuo šio piktybinio naviko sieke 567 atvejus, kurie sudare 16 proc. visų moterų mirties nuo vėžio atvejų [3,4].

Onkologinių pacientų gyvenimą galima pagerinti, laiku skiriant reabilitacinị gydymą, kai ligą galima išgydyti, ir kai numatoma bloga jos prognoze [5]. Reabilitacijoje išgijimas nuo vėžio suprantamas kaip ilgalaikis ir nepertraukiamas biopsichosocialinis procesas, kurio siekis pasirūpinti tinkama moters gyvenimo kokybe, grąžinant jai gyvenimo džiaugsmą, norą bendrauti ir tobuleti.

Tyrimai rodo, kad moterų viso gyvenimo fizinis aktyvumas gali sumažinti krūties vėžio riziką nuo 25 iki 40 procentu [6]. Bernstein ir kt. [7] tyrimas įrodè, kad viena valanda fizinio aktyvumo, kurio intensyvumas per 6,7 MET (meta - suvartotas deguonies kiekis per $1 \mathrm{~min} .1 \mathrm{~kg}$ kūno masès, esant sąlyginès ramybès būsenoje, $-3,5 \mathrm{mlO} 2 \mathrm{~kg}-1 \mathrm{~min}$ $-1)$, bent kartą per savaitę, ne mažiau kaip vienerius metus, sumažina riziką susirgti krūties vėžiu 20 proc., lyginant su fiziškai neaktyviomis moterimis. Kituose tyrimuose Gilliland ir kt. [8] nustate, kad įvairi fizinio aktyvumo veikla, pavyzdžiui, vaikščiojimas, bėgimas, plaukimas, važiavimas dviračiu ir kt., išreikšta funkcinio pajègumo vienetais (MET) (meta - suvartotas deguonies kiekis per $1 \mathrm{~min} .1 \mathrm{~kg}$ kūno 
masės, esant sąlyginès ramybės būsenoje, - 3,5 mlO2 kg -1 min -1), gali sumažinti krūties vèžio riziką nuo 40 iki 66 proc., jei moterys per savaitę pasiekia 25 MET valandas ir daugiau $[7,8]$. Reguliarus fizinis aktyvumas gali padèti išvengti ir ikivėžinių ligų bei gerybinių proliferacinių krūties audinio pakitimų. Fizinis aktyvumas laisvalaikiu gali padèti palaikyti organizmo energetinę pusiausvyrą, išvengti kaloringos mitybos ir sédimos gyvensenos keliamo antsvorio ir nutukimo pavojaus [6].

Viena iš sparčiausiai populiarèjančių fizinio aktyvumo formų yra šiaurietiškas ejimas. Ši fizinès veiklos forma aktyvuoja viso kūno raumenis, ejjimo metu naudojamos specialios lazdos priverčia dirbti pečių, rankų ir liemens raumenis [9]. Šiaurietiškas ejjimas gerina žmogaus judrumą, mažina jautrumą skausmui, gerina limfos nutekèjimą ir gali būti rekomenduojamas krūties vėžiu sergantiems pacientams, kaip saugi fizinè veiklos forma [10-13].

Tyrimo tikslas - fizinès reabilitacijos laikotarpiu nustatyti šiaurietiško ejjimo poveikį moterų psichomotoriniams parametrams, taikant spindulinị gydymą po krūties vėžio operacijos.

\section{Tyrimo objektas ir metodika}

Teorines tyrimo prielaidas sudare taikomosios fizinès veiklos mokslo kryptị veikianti visaverčio asmens funkcionavimo teorijos nuostata, kad į žmogų orientuota terapija padeda asmeniui realiai vertinti savo galimybes, suaktyvinti asmeninę veiklą ir siekti reabilitacijos tikslų [14].

Eksperimentinis tyrimas atliktas Nacionalinio vèžio instituto Fizinės medicinos ir reabilitacijos skyriuje 2015 $\mathrm{m}$. vasario - lapkričio mėnesiais. Tyrime dalyvavo krūties véžiu sergančios moterys, kurioms taikomas spindulinis gydymas. Spindulinio gydymo trukmè - 5 savaitès. Tyrimas vyko dviem etapais: I testavimas - spindulinio gydymo pradžioje, II testavimas - spindulinio gydymo pabaigoje. Tyrimas atliktas gavus Nacionalinio vėžio instituto leidimą bei laikantis etinių tyrimo aspektų.

Kontingentą sudare 40 moterų po piktybinio krūties auglio pašalinimo, po chemoterapinio gydymo ir kurioms tęsiant gydymą taikoma spindulinè terapija, taip pat pacientès, kurioms nebuvo taikyta chemoterapija, bet atlikas spindulinis gydymas. Respondentès patogiosios atrankos būdu suskirstytos ị dvi grupes: tiriamają $(n=20)$ ir kontrolinę $(n=20)$. Tiriamųu amžiaus vidurkis $54 \pm 5$ metai, iš kurių jauniausia tiriamoji - 36, o vyriausia - 72 metų. Kontrolinès grupès tiriamujų amžiaus vidurkis $57 \pm 6$ metai, iš kurių jauniausiai - 40, o vyriausiai - 74 metai. Visoms tyrimo dalyvèms gydymo metu paskirti 5 pečių juostos bei operuotos pusès rankos masažai ir 10 grupinių kineziterapijos procedūrų, kurių metu atliekami pratimai, gerinantys limfos nutekè- jimą, padedantys palaikyti ir (arba) didinti peties sąnario amplitudę. Tiriamajai grupei 4 savaites 3 kartus per savaitę taikytas šiaurietiškas èjimas po 60 min., o kontrolinei grupei rekomenduota 3 kartus per savaitę vaikščioti gryname ore po 60 min. Pacienčių psichomotoriniai parametrai vertinti 2 kartus - prieš spindulinį gydymą ir jo pabaigoje.

Moterims po krūties vèžio operacijos prieš spindulinị gydymą ir po jo goniometru matuota žasto judesių amplitudè (lenkimas, tiesimas ir atitraukimus). Plaštakos raumenų jèga vertinta hidrauliniu dinamometru. Sveikos ir operuotos pusès rankos apimtis matuota centimetrine juostele, norint ivvertinti limfedemos laipsnị. Tolerancija fiziniam krūviui vertinta 6 min. ejjimo testu. Vaizdinès analogijos skale (toliau -VAS) vertintas jaučiamas skausmas. Statistinè psichomotorinių parametrų analizė atlikta naudojant $\mathrm{R}$ programos paketą ir Microsoft Office Excel 2010 programą. Duomenų normalusis skirstinys nustatytas Shapiro-Wilk testu, vidurkiu skirtumų statistinis patikimumas įvertintas pagal Student (t) kriterijų, kai duomenys buvo pasiskirstę pagal normalujji skirstinị. Wilcoxon porinis testas taikytas, kai duomenys nepasiskirstę pagal normalujji skirstinį. Duomenų vidurkių skirtumai laikomi reikšmingais, kai $\mathrm{p}<0,05$.

\section{Rezultatai}

Prieš šiaurietišką ejjimą (toliau - ŠĖ) tiriamosios grupès žasto lenkimo amplitudès vidurkis I testavimo metu buvo $135 \pm 10^{\circ}$, po 12 užsiëmimų II testavimo metu - $152 \pm 7^{0}$, reikšmingai padidèjo 17 laipsnių $(\mathrm{p}<0,05)(1 \mathrm{pav}$.$) . Kontrolinėje$ grupeje po I ir II testavimo žasto lenkimo vidurkis statistiškai reikšmingai nepakito $(\mathrm{p}>0,05)$. Tarp tiriamosios ir kontrolinès grupių statistiškai reikšmingų skirtumų nerasta $(\mathrm{p}>0,05)$.

Tiriamosios grupès moterų žasto tiesimo amplitudès vidurkis prieš ŠĖ I testavimo metu buvo $43 \pm 2^{0}$, II testavimo metu $-48 \pm 1^{0}$. Lyginant tiriamosios grupès I ir II testavimo rezultatus, žasto tiesimo vidurkis statistiškai reikšmingai padidèjo $5^{0}(\mathrm{p}<0,05)(2$ pav.). Kontrolinèje grupejje žasto tiesimo vidurkis statistiškai reikšmingai nepakito $(p>0,05)$ (2 pav.). Tarp tiriamosios ir kontrolinès grupių statistiškai reikšmingų skirtumų nerasta $(\mathrm{p}>0,05)$.

Žasto atitraukimo amplitudès vidurkis tiriamojoje grupeje I testavimo metu buvo $139 \pm 12^{0}$, II testavimo metu $-157 \pm 7^{0}$. Palyginus gautus I ir II testavimo rezultatus, žasto atitraukimo vidurkis statistiškai reikšmingai padidejo $(p<0,05)(3$ pav.). Kontrolineje grupeje gauti I ir II testavimo rezultatai nebuvo statistiškai reikšmingi ( $\mathrm{p}>0,05)$. Tarp tiriamosios ir kontrolinès grupių statistiškai reikšmingų skirtumų nerasta $(\mathrm{p}>0,05)$.

Plaštakos suspaudimo jẻgos matavimo vidutinè reikšmė tiriamojoje ir kontrolinėje grupejje I testavimo metu buvo $27 \pm 3$ ir $25 \pm 3 \mathrm{~kg}$ ir atitiko vidutinị rekomenduotiną vidurkị 
(21-26 kg), o II testavimo metu ši reikšmė buvo $28 \pm 3 \mathrm{~kg}$; $26 \pm 3 \mathrm{~kg}$, tačiau operuotos pusès plaštakos suspaudimo jègos padidejjimas buvo statistiškai nereikšmingas ( $\mathrm{p}>0,05)$. Tarp tiriamosios ir kontrolinès grupių statistiškai reikšmingu skirtumų nerasta $(\mathrm{p}>0,05)$.

Tiriamosios grupès moterų operuotos pusès rankos apimties vidurkis I testavimo metu žasto srityje buvo $0,5 \pm 0,3 \mathrm{~cm}$, dilbio srityje ties alkūnès sąnariu $0,1 \pm 0,1 \mathrm{~cm}$, ties riešo sąnariu $0,1 \pm 0,1 \mathrm{~cm}$, o plaštakos apimties vidurkis buvo $0,1 \pm 0,1$ $\mathrm{cm}$. Po $12 \breve{\text { ŠE }}$ užsièmimų operuotos pusės rankos apimties vidurkis II testavimo metu žasto srityje buvo $0,1 \pm 0,1 \mathrm{~cm}$, dilbio srityje ties alkūnès sąnariu buvo $0,1 \pm 0,1 \mathrm{~cm}$, ties riešo sąnariu $0 \pm 0 \mathrm{~cm}$, o plaštakos apimties vidurkis buvo $0 \pm 0 \mathrm{~cm}$. Po ŠĖ programos taikymo operuotos pusès rankos apimties vidurkis ties žasto sritimi sumažèjo $0,4 \mathrm{~cm}$, dilbio srityje ties riešo sąnariu $0,1 \mathrm{~cm}$, o plaštakos apimtis sumažèjo 0,1 $\mathrm{cm}$. Lyginant gautus tiriamosios grupès I ir II testavimo rezultatus, po šiaurietiško ejjimo programos taikymo, rankos apimties vidurkis statistiškai reikšmingai sumažèjo žasto srityje $(\mathrm{p}<0,05)$.

Lyginant tiriamosios ir kontrolinės grupių I testavimo operuotos pusės rankos apimties vidurkius, nustatytas statistiškai reikšmingas skirtumas: dilbio srityje ties alkūnès sąnariu tarp grupių $0,4 \mathrm{~cm}(\mathrm{p}<0,05)$. Žasto srityje, dilbio srityje ties riešo sąnariu ir plaštakos apimtis statistiškai reikšmingai tarp grupių nesiskyrè ( $p>0,05)$. II testavimo metu tarp grupių nustatytas operuotos pusės rankos apimties statistiškai reikšmingas skirtumas: žasto srityje $0,8 \mathrm{~cm}$, dilbio srityje ties alkūnès sąnariu $0,4 \mathrm{~cm}$, dilbio srityje ties riešo sąnariu $0,3 \mathrm{~cm}$ ir plaštakos apimties $0,2 \mathrm{~cm}(\mathrm{p}<0,05)$.

Prieš ŠE tiriamosios grupès moterų 6 min. ejimą nueito atstumo vidutinè reikšmė I testavimo metu buvo $470 \pm 21$ metrų, po 12 ŠÉ užsiėmimų II testavimo metu ji buvo $507 \pm 25$ metrai. Po ŠÉ programos taikymo tiriamosios per 6 min. nuejo $37 \mathrm{~m}$ didesnị atstumą $(\mathrm{p}<0,05)$. Kontrolinejje grupejje prieš

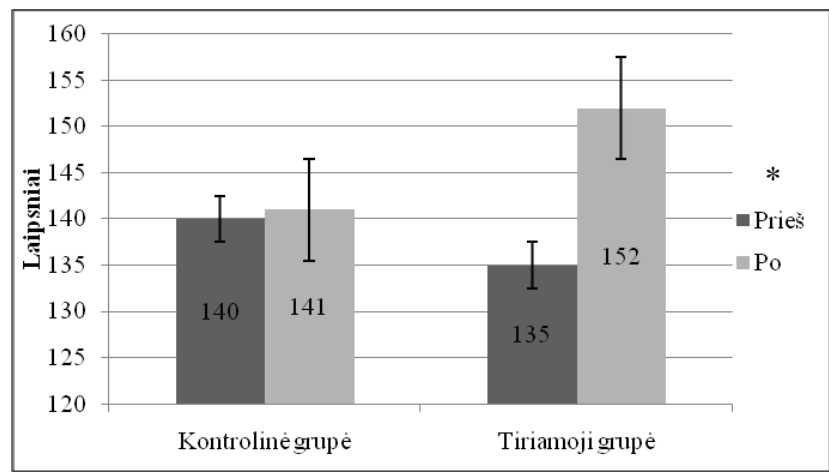

1 pav. Žasto lenkimo amplitudžių ịverčiai prieš ŠĖ ir po jo $*_{-} p<0,05$, tarp tos pačios grupés tiriamujų rodikliu prieš tyrima ir po jo tyrimą moteru per 6 min. nueito atstumo vidutinè reikšmė I testavimo metu buvo $440 \pm 29$ metru, po tyrimo II testavimo metu ji buvo $450 \pm 34$ metrų. Šešių minučių ejjimo testu statistiškai reikšmingas padidejimas nenustatytas $(\mathrm{p}>0,05)$.

Tiriamosios ir kontrolinès grupių I testavimo metu per 6 min. nueito atstumo vidurkių rezultatas reikšmingai nesiskyre $(p>0,05)$. Lyginant II testavimo per 6 min. nueito atstumo vidurkių rezultatus (4 pav.), nustatytas statistiškai reikšmingas $57 \mathrm{~m}$ skirtumas tarp tiriamosios ir kontrolinès grupès $(\mathrm{p}<0,05)$

Prieš ŠĖ programos taikymą, abiejų grupių tiriamieji įsivertino jaučiamą skausmą.

Tiriamosios grupès skausmo įsivertinimo rezultatai buvo: 40 proc. (8) -1 balas, 20 proc. (4) -2 balai, 15 proc. (3) -4 balai, 10 proc. (2) -0 balu, po 5 proc. (1) $-8,6$ ir 3 balai. Po ŠE programos taikymo: 50 proc. (10) -1 balas, po 15 proc. (3) -0 ir 4 balai, 10 proc. (2) -2 balai, po 5 proc. (1) -3 ir 5 balai. Lyginant tiriamosios grupès I ir II testavimo rezultatus, statistiškai reikšmingo pagerèjimo nenustatyta $(\mathrm{p}>0,05)$.

Kontrolinès grupès skausmo įsivertinimo rezultatai buvo: 25 proc. (5) - 2 balai, 20 proc. (4) - 5 balai, 10 proc. (2) -3 balai, po 15 proc. (3) - 0, 1 ir 4 balai. Po tyrimo: po 20 proc. (4) $-1,2,3$ ir 4 balai, 5 proc. (1) -0 ir 5 balai, 10 proc. (2) -6 balai. Lyginant kontrolinès grupès I ir II testavimo rezultatus, statistiškai reikšmingo pagerèjimo nenustatyta $(\mathrm{p}>0,05)$.

Lyginant tiriamosios ir kontrolinès grupės I testavimo VAS skausmo vidurkių rezultatus, statistiškai reikšmingo skirtumo nenustatyta $(p>0,05)$; lyginant II testavimo vidurkių rezultatus, nustatytas statistiškai reikšmingas skirtumas tarp tiriamosios ir kontrolinès grupių $(\mathrm{p}<0,05)$. Po tyrimo skausmo rodiklis tiriamojoje grupejje buvo mažesnis 1,15 balo (5 pav.).

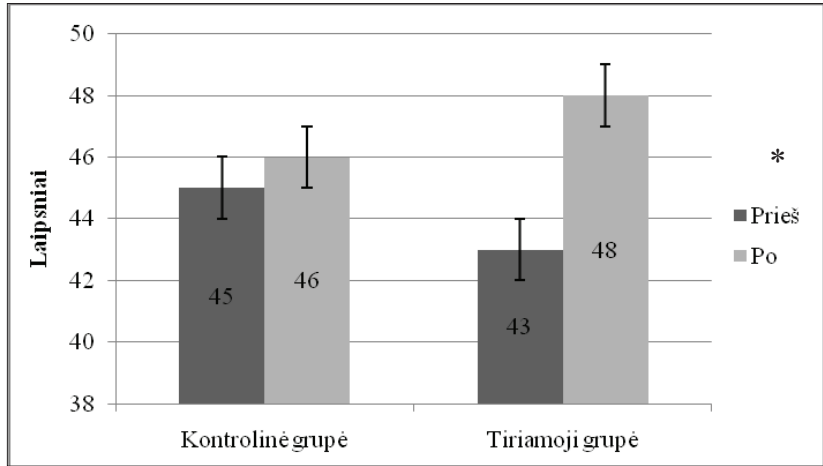

2 pav. Žasto tiesimo amplitudžių įverčiai prieš ŠĖ ir po jo $*_{-} p<0,05$, tarp tos pačios grupés tiriamujų rodikliai prieš tyrima ir po jo 


\section{Rezultatų aptarimas}

Ivertinus tyrimo rezultatus, galima teigti, kad Š́̇, taikomas spindulinio gydymo metu, teigiamai veikia moteru po krūties vėžio operacijos fizinius parametrus ir skausmo pojūtį.

Normali peties sąnario biomechanika sutrinka chirurginio bei spindulinio krūties vėžio gydymo metu dèl visos krūties ar dalies jos audinių pašalinimo, pooperacinių randų, kontraktūrų, skausmo baimès bei radiacijos sukeltos minkštujų audinių fibrozès [15]. Matuotų tiriamujų operuotosios pusès žasto judesių (lenkimo, tiesimo ir atitraukimo) amplitudžių vidurkiai prieš tyrimą buvo žemiau optimalių amplitudžių ivverčių. Po ŠĖ programos taikymo statistiškai reikšmingai padidejo tiriamosios grupès žasto judesių amplitudès. Panašius rezultatus gavo M. Rösner ir kiti tyrejjai [16]. Mūsų tyrimo duomenys sutapo su kitu autorių tyrimais, irodančiais, kad šiaurietiškas èjimas gerina pacienčių žasto judesių amplitudę per peties sąnarįi.

Plaštakos dinamometriją pasirinkome vienu iš savo tyrimo metodų todèl, kad dažniausios problemos, atsirandančios po kompleksinio krūties vèžio gydymo, yra skausmas,

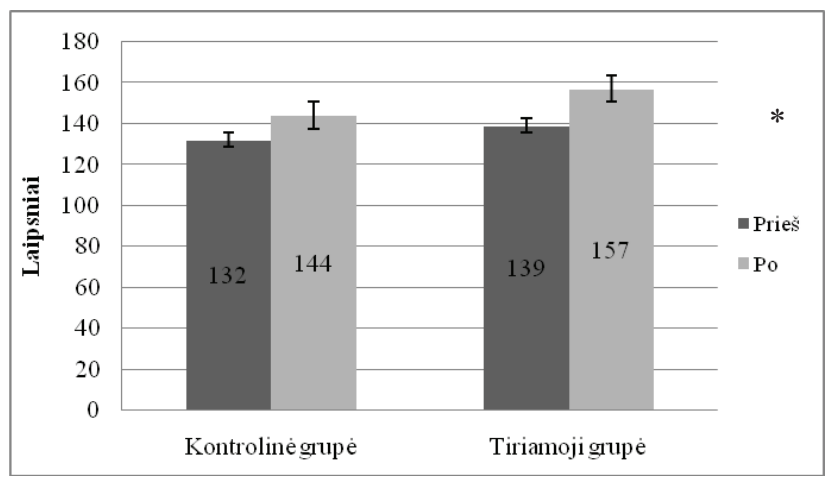

3 pav. Žasto atitraukimo amplitudžių įverčiai prieš ŠĖ ir po jo

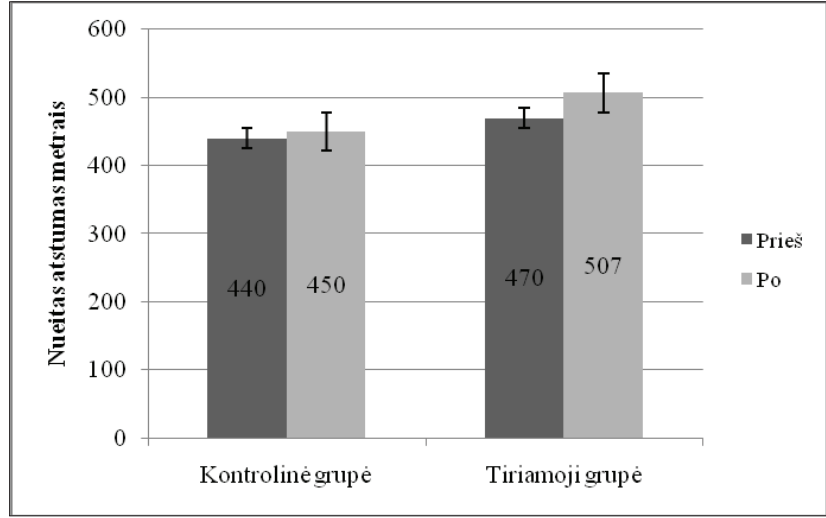

4 pav. Tiriamosios ir kontrolinès grupių per 6 min. nueitas atstumas prieš $\breve{S} \dot{E}$ ir po jo

${ }_{*}-p<0,05$, tarp tos pačios grupés tiriamuju rodikliu prieš tyrima ir po jo sumažejusi peties sąnario amplitudè bei plaštakos griebiamujų raumenų jèga ir limfedema [17]. Ši matavimo metodą nesunku taikyti ligoninès skyriaus aplinkoje. Mūsų tyrimo rezultatai tik iš dalies sutapo su $\mathrm{K}$. Mustian ir kt. autorių tyrimo rezultatais [18]. Respondenčiu operuotos pusès plaštakos griebimo jègos vidurkis $(25-29 \mathrm{~kg})$ ir prieš tyrimą, ir po jo buvo aukščiau nustatytų normų 55-60 metų amžiaus moterims $(21-26 \mathrm{~kg})$. Tokius jègos skirtumus galejjo lemti efektyvus pooperacinis bei sanatorinis (nepraejus 3 ménesiams po operacijos) reabilitacinis gydymas.

Fizinis aktyvumas turi teigiamą poveikị limfedemai. Tyrimai parode, kad pečių juostos pratimai neturi įtakos rankos apimties pokyčiams, net ir tiems pacientams, kuriems limfedema jau yra susiformavusi. Fizinis pasyvumas turi itakos rankos limfedemos formavimuisi [19]. Kiti autoriai nepateikia įrodymų, kad šiaurietiškas ejjimas gali sukelti ar pabloginti operuotos pusès rankos limfedemą $[10,11,13$, 20]. Pasipriešinimo pratimų mokymas taip pat nesukelia limfedemos moterims po krūties vèžio operacijos. Buvo įrodyta, kad laipsniškas pratimų programos planavimas yra veiksmingas, siekiant sumažinti galūnès limfedemą [21, 22]. Mūsų gauti tyrimo rezultatai ir kitų autorių atliktų tyrimų rezultatai ịrodo, kad efektyvi fizinè veikla turi teigiamą poveikị limfedemai.

Tyrimo rezultatai parodé, kad po ŠĖ programos taikymo statistiškai reikšmingai padidèjo nueito atstumo vidurkis tiriamojoje grupeje, lyginant gautus I ir II testavimo rezultatus $(p<0,05)$. Tarp tiriamosios ir kontrolinès grupès II testavimo rezultatai buvo statistiškai patikimi $(\mathrm{p}<0,05)$. Mustian $\mathrm{K}$. ir kt. savo tyrime taip pat taike 6 min. èjimo testą. Gauti rezultatai nebuvo statistiškai reikšmingi, tačiau intervencinių pratybų grupès gavo geresni fizinio pajègumo rezultatą, nei kontrolinè grupe po intervencijos [18]. Hu HF ir kiti [23] atliko atsitiktinių imčių kontroliuojamą tyrimą, kuriame mo-

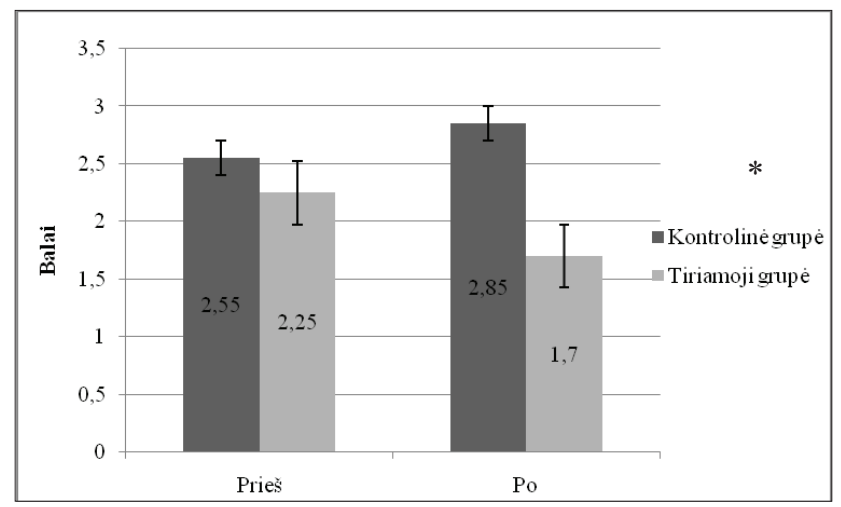

5 pav. Tiriamosios ir kontrolinès grupių VAS skausmo vidurkių palyginimas prieš Š́̇ ir po jo

$*_{-} p<0,05$, tarp tiriamosios ir kontrolinés grupiu rodikliu prieš tyrima ir po jo 
terys po krūties vėžio operacijos 3 kartus persavaitę penkias savaites vaikščiojo vidutiniu intensyvumu. Buvo vertinamas nuovargis ir nueitas atstumas per 6 minutes. Po tyrimo sumažèjo pacienčių nuovargis ir padidejjo nueitas atstumas per 6 min., tačiau gauti rezultatai nebuvo statistiškai reikšmingi tarp tiriamosios ir kontrolinès grupès [23]. Šių tyrimų rezultatai nesutampa su mūsų tyrimo rezultatais, nes autoriai negavo statistiškai reikšmingų duomenų tarp grupių.

Skausmui vertinti pasirinkome VAS skalę. Po tyrimo lyginant tiriamosios ir kontrolinès grupès skausmo II testavimo VAS rezultatus, buvo nustatytas statistiškai reikšmingas skirtumas tarp tiriamosios ir kontrolinès grupès $(p<0,05)$. Leibbrand ir kt. [24] aprašo, kad šiaurietiškas èjimas pagerino pacienčių peties sąnario mobilumą ir gyvenimo kokybę, po tyrimo buvo pastebimas sumažejęs jautrumas skausmui viršutinejje kūno dalyje [13].

Apibendrinant duomenis galima teigti, kad saugusir tinkamai adaptuotas fizinis aktyvumas gali sumažinti jautrumą skausmui bei pagerinti fizinius parametrus moterims po krūties vėžio operacijos.

\section{Išvados}

1. Reabilitacijos metu taikyta šiaurietiško ejjimo fizinè veiklos forma pagerino pacienčių fizinius parametrus: reikšmingai $(\mathrm{p}<0,05)$ pagerejo žasto lenkimo, tiesimo ir atitraukimo amplitudès funkcija ir fizinio krūvio tolerancija.

2. Nustatytas operuotos pusès rankos: žasto srityje, dilbio srityje ties alkūnès sąnariu, dilbio srityje ties riešo sąnariu ir plaštakos apimties statistiškai reikšmingas skirtumas $(p<0,05)$, sietinas su efektyviai taikyta šiaurietiško èjimo fizinès veiklos forma.

3. İvertinus gautus tyrimo rezultatus prieš taikant fizini krūvị ir po jo, subjektyviai jaučiamas skausmas sumažejjo tiriamojoje grupeje $(p<0,05)$. Aktyvi fizinè veikla turejo pozityvų poveikị tiriamosios grupès skausmo parametrui.

\section{Literatūra}

1. Valuckas K.P., Didžiapetrienė J., Atkočius V., Characiejus D. Onkologijos mokslo plètra Vilniaus universiteto Onkologijos institute. Medicina, 2004;40(12):1231-1238.

2. Juozaityte E. Krūties vèžys. Kaunas: Vitae Litera, 2009; 13(12):757-62.

3. Lietuvos vèžio registras, $2019<$ http://www.nvi.lt/index.php?$\underline{1413089819>}$

4. Steponavičienė L., Vincerževskienė I., Vansevičiūtė-Petkevičienė R., Smailytė G. Atrankinès mamografinès patikros programos igyvendinimas 2006-2017m. Lietuvoje. Visuomenès sveikata, 2019;1(84):39-46.

5. Aleknavičienė B., Valuckas K.P., Aleknavičius E. Onkologijos pagrindai šeimos gydytojui. Vilnius, 2005.
6. Kuzmickienė I., Petrauskaite Everatt R. Fizinis aktyvumas ir piktybinių navikų rizika: epidemiologinių tyrimų apžvalga. Visuomenès sveikata, 2011;4(55):8-1.

7. Clague J, Bernstein L. Physical Activity and Cancer. Current Oncology Report 14, 550-558 (2012).

8. Gilliland FD, Li YF, Baumgartner K, Crumley D, Samet JM. Physical activity and breast cancer risk in Hispanic and non-hispanic white women. Am J Epidemiol 2001 Sep 1; 154 (5):442-50.

9. Hagner-Derengowska M, Kałużny K, Hagner W, Kochański B, Plaskiewicz A, Borkowska A, Bronisz A, Budzyński J. (2015). The influence of a ten-week Nordic walking training-rehabilitation program on the level of lipids in blood in overweight and obese postmenopausal women. J Phys Ther Sci 2015;27(10):3039-3044.

https://doi.org/10.1589/jpts.27.3039

10. FischerM J, Krol-Warmerdam EM, Ranke G M, Vermeulen HM, Van der Heijden J, et al. Stick together: a Nordic walking group intervention for breast cancer survivors. J Psychosoc Oncol 2015;33(3):278-96. https://doi.org/10.1080/07347332.2015.1020465

11. Malicka I, Stefa'nska M, Rudziak M, et al. The influence of nordic walking exercise on upper extremity strength and the volume of lymphoedema in women following breast cancer treatment.Isokinetics and Exercise Science 2011;19, 295-304. https://doi.org/10.3233/IES-2011-0430

12. Sprod LK, Drum SN, Bentz AT, Carter SD, Schneider CM. The effects of walking poles on shoulder function in breast cancer survivors. Integr Cancer Ther. 2005;4(4):287-93. https://doi.org/10.1177/1534735405282212

13. Tschentscher M, Niederseer D, Niebauer J. Health benefits of Nordic walking: a systematic review. Am J Prev Med 2013;44(1),76-84. https://doi.org/10.1016/j.amepre.2012.09.043

14. Adomaitienė R., Augustinaitytė-Jurčikonienė G., Mikelkevičiūtė J., Morkūnienė A., Ostaševičienè V., Samsonienè L., Skučas K. Taikomoji neiggaliujų fizinè veikla. Lietuvos kūno kultūros akademija. Kaunas, 2003;13-14.

15. Kärki A, Simonen R, Mälkiä E, Selfe J. Impairments, activity limitations and participation restrictions 6 and 12 months after breast cancer operation. J Rehabil Med. 2005 May;37(3):180-8. https://doi.org/10.1080/16501970410024181

16. Rösner M. Evaluation eines Nordic-Walking-Programms bei Mammakarzinom-Patientinnen. Deutsche Zeitschrift für Sportmedizin 2011;62:120-125.

17. Rietman JS, Dijkstra PU, Debreczeni R, Geertzen JH, Robinson DP, De Vries J. Impairments, disabilities and health related quality of life after treatment for breast cancer: a follow-up study 2.7 years after surgery. DisabilRehabil 2004;26:78-84. https://doi.org/10.1080/09638280310001629642

18. Mustian K, Peppone L, Darling TV, Palesh O, Heckler CE, Morrow GR. A 4-week home-based aerobic and resistance 
exercise program during radiation therapy: a pilot randomized clinical trial. J Support Oncol 2009;7(5):158-167.

19. Baumann FT, Bloch W, Weissen A, Brockhaus M, Beulertz J, Zimmer P, Streckmann F, Zopf EM. Physical activity in breast cancer patients during medical treatment and in the after care - a review. Breast Care 2013;8:330-334.

https://doi.org/10.1159/000356172

20. Sprod LK, Drum SN, Bentz AT, Carter SD, Schneider CM. The effects of walking poles on shoulder function in breast cancer survivors.. Integr Cancer Ther 2005;4(4):287-93.

https://doi.org/10.1177/1534735405282212

21. Casla S, Hojman P, Márquez-Rodas I, López-Tarruella S, Jerez Y, Barakat R, Martín M. Running away from side effects: physical exercise as a complementary intervention for breast cancer patients.. ClinTransl Oncol 2015;17(3):180-96. https://doi.org/10.1007/s12094-014-1184-8

22. Kim DS, Sim YJ, Jeong HJ, Kim GC. Effect of active resistive exercise on breast cancer related lymphedema: a randomized controlled trial. Arch Phys Med Rehabil. 2010;91(12):1844-8. https://doi.org/10.1016/j.apmr.2010.09.008

23. Hu Hf, Li TC, Liu LC, Wu CT, Wang YJ. Effects of a walking program on fatigue and exercise capacity in post - surgery breast cancer women. Hu Li Za Zhi. 2013 Oct;60(5):53-63.

24. Leibbrand B, Kahnert H, Exner A.K. et al. Nordic walking trend or ideal performance training in brest cancer?. Onkologie. $2010 ; 33: 182-183$.

\section{WOMEN AFTER BREAST CANCER SURGERY REHABILITATION BY APPLYING NORDIC WALKING}

\section{E. Kalvaitienè, A. Gaupšienė, L. Samsonienè}

Keywords: physicalactivity, Nordic walking, rehabilitation, psychomotor parameters, breast cancer.
Summary

Nordic walking improves human mobility, reduces sensitivity to pain, improves lymph drainage and can be recommended for cancer patients as a safe form of physical activity. According to the provisions of "Fully functioning self-theory", we set the aims of this study: to assess the effect of Nordic walking to the psychomotor parameters of women during radiation therapy, after breast cancer surgery. Methods: 40 respondents (age $=55 \pm 19)$ took part in this study. The following psychomotor parameters were evaluated : hand muscle strength ( using dynamometer), the degree of lymphoedema (arm volume was measured using centimeter tape), pain (using pains visual scale (VAS) and tolerance to physical exertion (a 6-minute walk test). The measurements were performed twice, before physical activity and after. Results: Nordic walking was held 12 times; the duration of each session - 60 minutes. After the application of physical activity, following psychomotor parameter changes were found: at an average upper arms range of motion has improved - bending of the hand reached $17^{\circ}(51.5 \%)$, withdrawal $-18^{\circ}(56.75 \%)$, construction - $5^{\circ}(11.5 \%)$; at an average 6 min walk test improved about 36m ( 84.3\% ). After the application of physical activity pain decreased at an average of 0.5 points ( $32.3 \%$ ). Conclusions : as the form of physical activity, adapted Nordic walking improved patients psychomotor parameters: improved shoulders function, improved tolerance to physical activity, decreased pain and reduced risk of complications during radiotherapy treatment.

Correspondence to: laimute@samsonai.1t

Gauta 2020-01-23 